DOI: https://doi.org/10.31933/jemsi.v3i3

Received: 15 November 2021, Revised: 15 Desember 2021, Publish: 1 Januari 2022

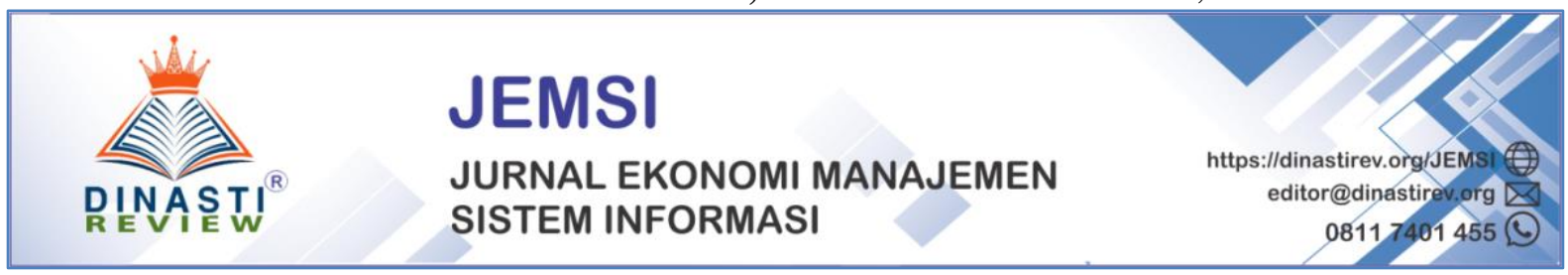

\title{
LITERATURE VIEW PENGORGANISASIAN: SDM, TUJUAN ORGANISASI DAN STRUKTUR ORGANISASI
}

\author{
Ganis Aliefiani Mulya Putri ${ }^{1}$, Srirahayu Putri Maharani ${ }^{2}$, Ghina Nisrina ${ }^{3}$ \\ ${ }^{1}$ Mahasiswa Program Sarjana Fakultas Ekonomi dan Bisnis, Universitas Bhayangkara Jakarta \\ Raya, email: ganisjung05@gmail.com \\ ${ }^{2}$ Mahasiswa Program Sarjana Fakultas Ekonomi dan Bisnis, Universitas Bhayangkara Jakarta \\ Raya, email: maharanip239@gmail.com \\ ${ }^{3}$ Mahasiswa Program Sarjana Fakultas Ekonomi dan Bisnis, Universitas Bhayangkaraa \\ Jakarta Raya, email: ghinanisrina211201@gmail.com
}

\section{Korespondensi Penulis: Ganis Aliefiani Mulya Putri ${ }^{1}$}

Abstrak: Pengorganisasian adalah suatu proses pengeklasifikasian dan pembagian aktivitas/kerja dalam tujuan yang diharapkan sebuah organisasi maka dengan pengorganisasian dapat membagi tugas dan tanggung jawab diantaranya oleh para pengurus agar semua dapat berjalan efektif. Dalam melakukan pengorganisasian artikel ini meriview faktor-faktor yang mempengaruhinya, yaitu: Sumber Daya Manusia, Tujuan, dan Struktur Organisasi. suatu studi literatur Manajemen Sumberdaya Manusia. Tujuan penulisan artikel ini guna membangun hipotesis pengaruh antar variabel untuk digunakan pada riset selanjutnya. Hasil artikel literature review ini adalah: (1) Pengelolaan manusia atau sumber daya manusia dalam sebuah organisasi mempengaruhi proses pengorganisasian berkaitan dengan pelaksanaan organisasi itu sendiri. (2) Tujuan organisasi mempengaruhi pengorganisasian dimana dalam kegiatannya organisasi harus berorientasi tujuan organisasi. (3) Struktur organisasi mempengaruhi pengorganisasian karena struktur organisasi mengatur diantaranya pembagian tugas dan wewenang dalam suatu peta konsep organisasi sederhana.

Kata Kunci: Pengorganisasian, SDM , Tujuan Organisasi , Struktur Organisasi

\section{PENDAHULUAN}

\section{Latar Belakang Masalah.}

Pada era globalisasi ini, kebutuhan semakin banyak dan tuntutan semakin beragam. Dalam upaya memenuhi kebutuhan dan tuntutan tersebut individu terpaksa harus beradaptasi menyesuaikan diri agar dapat selalu memenuhi kebutuhannya. Contohnya, kebutuhan seseorang yang hidup sendiri tentu akan berbeda dengan kebutuhan berkeluarga, dengan gaji yang sama seseorang yang bekeluarga tentunya harus lebih giat dalam bekerja atau mungkin mencari penghasilan tambahan untuk memenuhi tuntutan hidup. 
Dalam upaya pemenuhannya, manusia-manusia yang memiliki kebutuhan yang sama ini berkumpul dan melakukan kinerja-kinerja untuk memenuhi tuntutan hidup. Perkumpulan idnividu-individu yang memiliki kepentingan yang sama ini sering disebut organisasi. Organisasi juga didefinisikan oleh James D. Mooney sebagai bentuk setiap perserikatan manusia dalam mencapai target atau tujuan yang sama. Adapun bentuk organisasi ini beragam dikarenakan tujuan yang juga berbeda-beda, diantaranya adalah organisasi kemasyarakatan/sosial, organisasi kemahasiswaan, organisasi politik, organisasi kenegaraan dan lainnya.

Faktanya, bahwa kebanyakan dari masyarakat menjalani Sebagian besar kehidupan dalam organisasi-organisasi diantaranya, organisasi pertama yang dinamakan keluarga, adapun organisasi pendidikan, yaitu sekolah, lalu ada juga organisasi profesi atau perusahaan. Tujuan dalam melaksanakan organisasi ini ialah untuk mencapai hal-hal yang tertentu dan tidak dapat dilaksanakan secara individual. Organisasi merupakan elemen yang amat diperlukan di dalam kehidupan manusia modern, dimana organisasi ini membantu manusia sedikitnya dalam kelangsungan pengetahuan, ilmu pengetahuan dan pemenuhan kebutuhan dalam keberlangsungan hidup.

Namun, pembentukan organisasi bukanlah hal yang mudah. Banyak hambatan yang akan dihadapi dalam mewujudkan organisasi yang sesuai dengan tujuan. Manusia dan cara mengelola sumber daya manusia dalam suatu organisasi menjadi penting karena semakin banyak sumber daya lain menjadi kurang kekuatan untuk dapat tetap bersaing dalam dunianya. Keberadaan manajemen sumber daya manusia dalam suatu organisasi bertujuan untuk meningkatkan kontribusi karyawan terhadap organisasi dalam rangka mencapai tujuan organisasi. Hal ini mampu dipahami karena semua kegiatan organisasi dalam pencapaian tujuannya bergantung kepada manusia yang mengolah organisasi. Hanya organisasi yang memiliki sumber daya manusia yang berkualitas yang akan mampu memenangkan persaingan dan dapat mengembangkan organisasi.

Terkait dengan pemaparan tersebut, maka perlu dilakukan identifikasi faktor-faktor yang mempengaruhi pembentukan organisasi atau pengorganisasian. Hal ini pula didukung oleh (Winardi, 2008) bahwa target keorganisasian untuk perubahan, misalnya: manusia, teknologi, pekerjaan, struktur keorganisasian, proses, kultur, dan manajemen. Terkait dengan kenyataan ini menunjukkan bahwa betapa pentingnya sebuah proses pembentukan organisasi pendidikan sehingga dapat meningkatkan kinerja organisasi itu sendiri. Hal ini sebagaimana dijelaskan oleh (Mayston, 2003) bahwa pendidikan menyediakan area penting dari penerapan teknik-teknik evaluasi kinerja yang dimaksudkan untuk meningkatkan kinerja layananlayanan publik.

Pengorganisasian dapat terbentuk karena suatu proses pengelompokan serta pembagian aktivitas dalam tujuan yang diharapakan oleh sebuah organisasi bahwa dengan adanya organisasi dapat mengelompokkan tugas dan tanggung jawab anggota. Pengorganisasian juga 
diartikan sebagai aktivitas dasar manajemen yang dilaksanakan untuk mengatur sumber daya yang diperlukan.

Fungsi Pengorganisasian guna menetapkan cara memilah pekerjaan yang dapat dikelola dengan baik. Organisasi ini biasanya dibentuk dengan beberapa faktor diantaranya sumber daya manusia atau subjek pelaksanan organisasi, visi atau tujuan yang sama, dan struktur atau pembagian tugas organisasi.

Manusia merupakan unsur penting, melalui pengorganisasian manusia serta tugas yang saling berhubungan dimana manusia dibimbing bekerja secara efektif dalam pembagian pengelompokkan kerja. Sering didefinisikan sebagai garis hierarki, selebihnya struktur organisasi memiliki peran yang lebih penting bagi suatu organisasi dimana terdapat gambaran umum pembagian ranah wewenang dan tanggun jawab anggota atau kelompok anggota agar terwujudnya tujuan organisasi. Bahkan beberapa elemen pendukung dirumuskan oleh struktur organisasi diantaranya adalah perumusan job description anggota, perumusan wewenang, hingga penentuan imbalan yang diterima setiap anggota untuk kinerjanya. Dalam beberapa kasus, struktur organisasi juga dapat mempengaruhi motivasi anggota untuk mencapai posisi yang lebih tinggi dengan hierarki yang jelas. Selain itu, menyusun struktur organisasi yang jelas juga dapat mengurangi konflik internal dalam pemindahan tanggung jawab atau persengketaan wewenang.

Proses pengorganisasian yang baik akan meningkatkan peluang suatu organisasi untuk mencapai tujuan. Struktur organisasi yang menunjukkan struktur dan susunan paradigma tetap hubungan diantara fungsi, bagian maupun posisi orang yang menunjukkan tingkatan, tugas wewenang dan tanggung jawab yang berbeda dalam suatu organisasi.

Pada artikel ini, akan dibahas lebih lanjut terkait hubungan manusia, tujuan organisasi dan struktur organisasi dalam pengorganisasian.

\section{Rumusan Masalah.}

Berdasarkan latar belakang, maka dapat di rumuskan permasalahan yang akan dibahas guna membangun hipotesis untuk riset selanjutnya yaitu:

1. Apakah SDM berpengaruh terhadap Pengorganisasian ?

2. Apakah tujuan organisasi berpengaruh terhadap Pengorganisasian?

3. Apakah struktur organisasi berpengaruh terhadap Pengorganisasian?

\section{KAJIAN TEORI}

\section{Pengorganisasian}

Pengorganisasian merupakan fungsi manajemen dan suatu proses yang dinamis, sedangkan organisasi merupakan alat statis. Pengorganisasian dapat juga diartikan penentuan pekerjaan yang dapat dilakukan, pengelompokkan tugas dan membagikan pekerjaan pada setiap karyawan, penentuan departemen (subsistem) serta penentuan hubungan. 
Menurut (Hasibuan, Manajemen Sumber Daya Manusia, 2011), pengorganisasaian merupakan proses penentuan, pengelompokkan serta pengaturan berbagai aktifitas yang diperlukan untuk mencapai tujuan, menempatkan orang pada setiap aktifitas, menyediakan alat yang dibutuhkan, menetapkan wewenang yang secara relative kepada setiap individu yang akan melakukan aktifitas tersebut. Pengorganisasian juga suatu proses stabilisasi perilaku efektif dari hubungan antar manusia kemudian dapat berjalan secara maksimal serta meningkatkan kepuasan seseorang dalam tujuan mencapai target atau tujuan (George $\mathrm{R}$ Terry).

Dalam proses pengorganisasian, terdapat teori yang dirumuskan oleh ahli, diantaranya, yaitu:

\section{a) Teori Fusi (The Fusion Theory)}

Teori Fusi berisi mengenai organisasi yang berfokus pada bekerjanya proses fusi dalam bidang pengorganisasian. Menurut teori ini, sebuah organisasi berusaha untuk menggunakan individu yang berfungsi menjalankan tujuan, individu mengharapkan tujuan itu sendiri melalui organisasi yang bersangkutan. Titik berat menempatkan atas kelakuan, yang besar berhubungan dengan peran, dan tidaklah pekerjaan modifikasi. Individu yang berkaitan dengan mencari harta, harmoni, kebebasan pemungutan keputusan yang melalui suatu proses personalisasi. Sebaliknya organisasi yang bersangkutan meningkatkan proses sosialisasi yang diperuntukan oleh pembagian tugas dan praktek balas jasa dan hukuman. Proses fusi memicu fusi antara proses personalisasi dan proses sosialisasi.

b) Teori Sistem (The System Theory)

Pada teori sistem, pengorganisasian dianggap sebagai suatu sistem variabelvariabel yang saling berpengaruh satu sama lain.partikel pokok sistem pengorganisasian adalah individu, organisasi formal atau penyusunan fungsi-fungsi, organisasi informal, prototipe kelakuan terbalik yang timbul dari syarat-syarat kontribusi organisasi yang bersangkutan dan presepsi kontribusi individu, dan lingkungan fisik dimana pekerjaan dilaksanakan.

c) Teori Kuantitatif (The Quantitative Theory)

Teori kuantitatif memberikan kondisi objektifitas kepada studi tentang pengorganisasian walaupun teori ini hanya mencakup suatu bagian dari pertimbanganpertimbangan yang mempengaruhi pekerjaan pengorganisasian. Misalnya kepemimpinan, lingkungan dan komunikasi ditiadakan dalam Analisa yang bersangkutan. Faktor-faktor yang bisa dihitung ditunjukkan terhadap faktor-faktor seperti semisal besar integritas organisasi, jumlah ketentuan-ketentuan yang dibuat oleh setiap manajer dan jumlah pekerjaan yang diselesaikan. Dapat dipastikan bahwa versi-versi matematis akan disempurnakan untuk studi pengorganisasian.

Adapun komponen-komponen pengorganisasian, yaitu pekerjaan (work), pegawaipegawai (employes), hubungan-hubungan (Relationships), dan lingkungan (environtment). Pekerjaan, dimana fungsi-fungsi yang dijalankan berasal dari tujuan-tujuan yang dinyatakan itu. Mereka merupakan landasan bagi organisasi. Fungsi-fungsi itu dipisah-pisahkan dalam 
sub-sub fungsi yang dilakukan karena, pertama, penguraian pekerjaan dikalangan sebuah regu menghendaki, lalu pekerjaan itu harus dibagi-bagi. Kedua, juru pekerjaan mewajibkan satuan-satuan tugas yang minim.Kelompok aktivitas kerja dibentuk atas dasar persamaan pekerjaan maupun efisiensi, yakni fungsi tertentu, apabila ditempatkan didalam kelompok yang terlaksana dengan baik.

Pegawai atau employes merupakan subjek yang mengerjakan tugas/pekerjaan-pekerjaan organisasi. Penugasan akan memberikan penetapan sepenuhnya terhadap perhatian pegawai , perilaku, pengalaman dan kecakapan. Penetapan ini merupakan alat vital dalam mengorganisir. penugasan pada seseorang yang terdiri dari suatu bagian dari pekerjaan divisi kerja organisasi meliputi dalam beberapa hal.

Hubungan yang merupakan bagian penting dalam pengorganisasian. Contohnya pegawai dengan pekerjaan, interaksi pegawai dengan yang lain dari satuan unit pekerjaan dengan pekerja lainnya, merupakan isu yang menentukan pengorganisasian. Keselarasan dan kesatuan usaha mungkin hanya kalau hubungan-hubungan ini baik. Kebanyakan persoalan dalam pengorganisasian, sampai beberapa jauh, mengaitkan kesulitan-kesulitan hubungan.

Lingkungan berisi alat fisik dan iklim umum, dimana para pegawai akan melakukan kegiatan kerja. Lokasi, peralatan, meja-meja, formulir-formulir, penerangan, semangat umum, dan sikap-sikap merupakan contoh-contoh dari faktor-faktor yang membentuk lingkungan. Pengorganisasian sudah banyak di teliti oleh peneliti sebelumnya di antaranya adalah (Limakrisna et al., 2016), (Harini et al., 2020), (Prayetno \& Ali, 2017), (Elmi et al., 2016), (Ridwan et al., 2020).

\section{SDM}

SDM ialah suatu rancangan dari berbagai sistem formal pada sebuah organisasi dengan tujuan memastikan penggunaan keahlian manusia secara efektif serta efisien untuk mencapai tujuan organisasi / perusahaan sesuai dengan tekad yang dituju. Pada dasarnya, SDM berwujud manusia yang dipekerjakan dalam sebuah organisasi yang menjadi aktivis, teoretikus serta perencanaan guna mencapai tujuan organisasi tersebut. Agar bisa diucapkan sebagai sebuah organisasi maka sebuah perserikatan serta perkumpulan tentu harus memiliki anggota. Sebuah organisasi minimal harus mempunyai anggota 2 orang atau lebih.

Sumber daya manusia (SDM) merupakan faktor yang sangat penting yang tidak bisa dipisahkan dari suatu organisasi maupun perusahaan. SDM terbilang kunci yang memastikan perkembangan perusahaan. SDM berwujud manusia yang dipekerjakan dalam sebuah organisasi sebagai penggerak, pemikir dan perencana guna mencapai tujuan organisasi. Perkembangan karyawan bukan sebagai sumber daya belaka, melainkan berbentuk modal atau aset bagi budaya serta organisasi. Lalu terbitlah istilah baru di luar H.R. (Human Resources), yaitu H.C. atau Human Capital. SDM dilihat sebagai aset utama, adapun aset yang bernilai yang dapat dilipatgandakan, dikembangkan (bandingkan dengan portfolio investasi) dan juga bukan sebaliknya sebagai liability (beban, cost). Di sini perspektif SDM 
sebagai investasi bagi budaya atau organisasi lebih mengemuka. Menurut Muhammad Yusuf (2016).

SDM dibagi menjadi dua bagian, yaitu pengertian mikro dan makro. SDM secara mikro yaitu individu yang bekerja serta menjadi anggota suatu perusahaan dan bisa dikatakan sebagai pegawai, buruh, karyawan, tenaga kerja dan sebagainya. Adapun pengertian SDM secara makro ialah warga suatu negara yang telah melewati usia angkatan kerja, baik yang belum maupun yang sudah bekerja.

Berdasarkan teori (Jamarah, 2017) yaitu komponen data-data SDM guna mengembangkan dan mengelola SDM dalam mengembangkan usaha yaitu:

a) Kualitas pekerjaan dan inovatifnya

Kualitas kerja merupakan hasil yang dapat diukur dengan efektifitas dan efisiensi suatu pekerjaan yang dilakukan oleh sumber daya manusia atau sumber daya lainnya dalam pencapaian tujuan atau sasaran perusahaan dengan baik dan berdaya guna. Inovatif yaitu Kemampuan seseorang dalam menggunakan kemampuan dan keahlian untuk menghasilkan karya baru.

b) Kejujuran dalam bekerja

Kejujuran akan berdampak positif serta membawa kepada kehidupan yang lebih baik. Pentingnya kejujuran dalam bekerja wajib kita terapkan sejak usia dini agar senantiasa bersikap jujur dalam berbagai tindakan.

c) Kehadiran dalam bekerja

Kehadiran seorang karyawan sebagai sebuah kewajiban yang harus dilakukan kecuali ada hal-hal lain yang sifatnya penting dan hal tersebut dapat dipertanggung jawabkan oleh yang bersangkutan. Sistem kehadiran karyawan sudah ditentukan dan diatur dari perusahaan dan kemudian duterapkan di masing-masing bagian.

d) Sikap dalam bekerja

Sikap positif dibutuhkan jika terjadinya masalah dalam pekerjaan dan disarankan untuk berusaha mencari berbagai jalan untuk mencari solusi permasalahannya Inisiatif dan kreatif.

Seseorang dapat dinyatakan kreatif jika mampu membuat atau menciptakan sesuatu, hasil pemikiran dari orang yang belum pernah melihat hal yang dibuatnya.

Kerjasama sangat dibutuhkan dalam bekerja, karena kerjasama akan membantu kemahiran dalam bekerja.

e) Keandalan dalam bekerja

Keandalan dalam suatu pekerjaan artinya berusaha menjalani ketaatan terhadap prinsip moral dan etika kerja, mampu mengembangkan karakter diri yang taat moral dan etika, mampu menjaga kejujuran dan keikhlasan hati untuk berkontribusi terhadap kemajuan perusahaan, serta mampu membebaskan diri dari kontrol dan pengaruh negatif orang lain.

f) Pengetahuan tentang pekerjaan

Pengetahuan yang harus dimiliki setiap tenaga kerja agar mampu melaksanakan pekerjaan dengan baik serta maksimal. 
Tanggung jawab terhadap pekerjaan berarti menyelesaikan sebuah masalah dengan maksimal. Ketika menyelesaikan masalah harus bersikap bijaksana dalam menentukan cara untuk menyelesaikan masalah tersebut. Guna rasa tanggung jawab yang telah kita kerjakan dapat berhasil dengan baik. Sehingga masalah itu kita dapat selesaikan dengan maksimal.

g) Pemanfaatan waktu dalam bekerja

Waktu merupakan aset yang paling sulit untuk dikelola. Maka dari itu kita harus dapat menggunakan waktu dengan lebih efisien.

Fungsi eksploitasi tenaga kerja meliputi penerapan program ekonomis maupun nonekonomis, yang memberikan kenyamanan bagi pekerja, sehingga mereka dapat bekerja dengan efektif dan efisien.

Tujuan manajemen SDM yaitu meningkatkan produktivitas dalam perusahaan melalui berbagai cara serta bertanggung jawab secara strategis dan teratur. Adapun tujuan peningkatan sumber daya manusia dapat ditingkatkannya kapabilitas dan juga sikap anggota organisasi agar terlihat lebih efektif serta efisien dalam mencapai tujuan organisasi (Martoyo, 1992).

\section{Tujuan Organisasi}

Organisasi ialah proses mempertemukan pekerjaan yang orang atau kelompok harus melakukan dengan kekuasaan yang diperlukan untuk pelaksanaannya, adapun kewajiban yang dilaksanakan itu dapat memberikan saluran terbaik bagi penyelenggara usaha yang efisien, teratur, positif, dan terkoordinasikan. (John M. Pfiffner dan S. Owen Lane , 1951)

Organisasi harus memiliki tujuan yang akan dicapai. Tujuan tersebut dapat dinilai dari beberapa aspek yaitu metode, paradigma, serta program sampai tahap akhir dari pekerjaan yang dikerjakan oleh anggota organisasi. Menurut Kamus Besar Bahasa Indonesia, tujuan mempunyai arti haluan yang dituju, arah yang dituju. Makna yang yang bisa juga dipakai dalam pengertian tujuan adalah sebagai keinginan. Pengertian tersebut menunjukan bahwa tujuan itu tidak berdiri sendiri tujuan merupakan suatu keadaan yang lebih baik yang ingin dicapai di masa yang akan datang. Untuk mendapat tujuan yang lebih baik pada masa yang akan datang dibutuhkan kinerja yang lebih baik. Kinerja merupakan petunjuk arah bagi tujuan yang akan dicapai yang dilakukan oleh organisasi, kelompok, maupun individu.

\section{Struktur Organisasi}

Struktur organisasi perusahaan yang membantu menentukan kesuksesan. Struktur organisasi dideskripsikan sebagai sistem yang digunakan guna mendefinisikan suatu organisasi. Adapun jenis struktur organisasi. Pada struktur organisasi mempunyai kelebihan dan kekurangan dan hanya berfungsi untuk perusahaan ataupun organisasi di dalam situasi tertentu atau pada suatu titik tertentu dalam siklus hidup. Menurut Gill Corkindale dari Harvard University menjelaskan desain dan juga struktur organisasi yang buruk menghasilkan kontradiksi yang membingungkan: kebingungan dalam suatu peran, dan 
kurangnya koordinasi antar fungsi, kegagalan untuk berbagi inovasi, dan pengutipan keputusan yang lambat membuat manajer menjadi kompleks, stres dan konflik.

Tabel 1: Penelitian terdahulu

\begin{tabular}{|c|c|c|c|c|}
\hline $\begin{array}{l}\mathrm{N} \\
\mathrm{O}\end{array}$ & $\begin{array}{l}\text { Author } \\
\text { (tahun) }\end{array}$ & Hasil Riset terdahulu & Persamaan dengan artikel ini & $\begin{array}{l}\text { Perbedaan dengan } \\
\text { artikel ini }\end{array}$ \\
\hline 1 & $\begin{array}{l}\text { Susandi } \\
\text { Prihayan } \\
\text { to }(2012)\end{array}$ & $\begin{array}{l}\text { Budaya organisasi dan } \\
\text { motivasi mempengaruhi } \\
\text { kinerja karyawan }\end{array}$ & $\begin{array}{l}\text { Terdapat variabel kinerja } \\
\text { karyawan (optimalisasi } \\
\text { pengorganisasian) }\end{array}$ & $\begin{array}{l}\text { Kinerja karyawan } \\
\text { (Sumber Daya } \\
\text { Manusia/Manusia) } \\
\text { sebagai variabel bebas }\end{array}$ \\
\hline 2 & $\begin{array}{l}\text { Naily El } \\
\text { Muna } \\
(2012)\end{array}$ & $\begin{array}{l}\text { Pengembangan karir dan } \\
\text { pemeliharaan SDM } \\
\text { terhadap Produktivitas } \\
\text { Kerja Karyawan } \\
\end{array}$ & $\begin{array}{l}\text { SDM mempengaruhi kerja } \\
\text { karyawan (optimalisasi } \\
\text { pengorganisasian) }\end{array}$ & $\begin{array}{l}\text { Terdapat variabel lain } \\
\text { diantaranya Tujuan dan } \\
\text { Struktur Organisasi. }\end{array}$ \\
\hline 3 & $\begin{array}{l}\text { Sevvy } \\
\text { Yossa } \\
\text { dan } \\
\text { Zunaida } \\
\text { h (2013) }\end{array}$ & $\begin{array}{l}\text { Akibat kemampuan } \\
\text { karyawan, pembagian } \\
\text { tugas dan motivasi } \\
\text { terhadap kinerja karyawan }\end{array}$ & $\begin{array}{l}\text { Pembagian tugas (struktur } \\
\text { organisasi yang jelas) dan } \\
\text { motivasi (tujuan) berpengaruh } \\
\text { terhadap kinerja karyawan } \\
\text { (optimalisasi pengorganisasian) }\end{array}$ & $\begin{array}{l}\text { Terdapat variable lain } \\
\text { yaitu pengelolaan } \\
\text { manusia/SDM }\end{array}$ \\
\hline 4 & $\begin{array}{l}\text { Putra, S. } \\
\text { W. } \\
(2015) \text {. }\end{array}$ & $\begin{array}{l}\text { Komitmen } \\
\text { organisasi } \\
\text { berpengaruh positif } \\
\text { dan signifikan } \\
\text { terhadap kinerja } \\
\text { karyawan }\end{array}$ & $\begin{array}{l}\text { menunjukkan bahwa } \\
\text { Komitmen organisasi } \\
\text { berpengaruh positif } \\
\text { terhadap Kinerja } \\
\text { Karyawan, (optimalisasi } \\
\text { pengorganisasian) }\end{array}$ & $\begin{array}{l}\text { Terdapat variable lain } \\
\text { yaitu Komitmen } \\
\text { Organisasi }\end{array}$ \\
\hline 5 & $\begin{array}{l}\text { Muizu } \\
(2014)\end{array}$ & $\begin{array}{l}\text { pengujian dari } \\
\text { hipotesis menunjukan } \\
\text { kepemimpinan } \\
\text { berpengaruh secara } \\
\text { signifikan, baik parsial } \\
\text { maupun simultan terhadap } \\
\text { kinerja karyawan }\end{array}$ & $\begin{array}{l}\text { memiliki kesamaan } \\
\text { variabel berupa kinerja } \\
\text { karyawan }\end{array}$ & $\begin{array}{l}\text { Memiliki variable lain } \\
\text { yaitu kepemimpinan }\end{array}$ \\
\hline 6 & $\begin{array}{l}\text { Gogy } \\
\text { Bara } \\
\text { Kharism } \\
\text { a } 2013\end{array}$ & $\begin{array}{l}\text { bagaimana gambaran } \\
\text { Budaya Organisasi, } \\
\text { Lingkungan Kerja } \\
\text { dan Kinerja Kayawan }\end{array}$ & $\begin{array}{l}\text { mendeskripsikan pengaruh } \\
\text { budaya Organisasi dan } \\
\text { Lingkungan Kerja terhadap } \\
\text { Kinerja Karyawan }\end{array}$ & $\begin{array}{l}\text { Terdapat variable lain } \\
\text { diantaranya Budaya } \\
\text { Organissi dan } \\
\text { Lingkungan Kerja } \\
\text { terhadap Kinerja } \\
\text { Karyawan }\end{array}$ \\
\hline
\end{tabular}

\section{METODE PENULISAN}

Metode penulisan artikel ini ditulis dengan menggunakan metode kualitatif dan studi literature atau Library Research. Mengkaji Buku-buku literature sesuai dengan teori yang di bahas khusunya ruang lingkup Manajemen Sumber Daya Manusia (MSDM)/Manajemen Pemasaran. Selain itu menganalisis artikel-artikel ilmiah yang bereputasi dan juga artikel ilmiah dari jurnal yang belum bereputasi. Artikel ilmiah yang di citasi bersumber dari Mendeley dan Scholar Google. Dalam penelitian kualitatif, kajian pustaka digunakan secara konsisten dengan asumsi metodologis. Adapun digunakan secara induktif sehingga tidak mengarah kepada pertanyaan-pertanyaan yang dikemukakan oleh peneliti. Salah satu alasan utama untuk melakukan penelitian kualitatif ialah bahwa penelitian tersebut bersifat 
eksploratif, (Ali \& Limakrisna, 2013) Yang akan dibahas secara mendalam pada bagian yang berjudul "Pustaka Terkait" (Related Literature) atau Kajian pustaka ("Review of Literature"), Menjadi dasar perumusan hipotesis yang selanjutnya akan menjadi dasar untuk melakukan perbandingan dengan hasil atau temuan-temuan yang dianalisis dalam penelitian (Ali \& Limakrisna, 2013)

\section{HASIL DAN PEMBAHASAN}

\section{Pengaruh SDM terhadap Pengorganisasian}

Menurut beberapa para ahli Sumber Daya Manusia (SDM) merupakan jasa atau usaha kerja yang dapat diberikan dalam proses produksi. SDM dapat dideskripsikan sebagai kualitas usaha yang dapat dilaksanakan oleh seseorang dalam kurun waktu tertentu untuk menghasilkan barang dan jasa. (Sumarsono, 2006). Perencanaan sumber daya manusia adalah proses pengkajian kebutuhan sumber daya manusia secara teratur untuk memastikan bahwa beberapa karyawan yang diperlukan sesuai dengan ketentuan dan keahlian yang sudah ditetapkan pada saat diperlukan (Mondy R. a., 1995)

Adapun fungsi perencanaan Sumber Daya Manusia (SDM) merupakan pembagian kedudukan dalam suatu perusahaan yang dapat memastikan tugas, tujuan, keahlian, dan kemampuan yang dibutuhkan. Peningkatan rencana yang berfungsi untuk memenuhi kebutuhan. Aktivitas perencanaan kualitas dan kuantitas Sumber Daya Manusia (SDM) merupakan pekerjaan manajemen sumber daya manusia yang berisi ketidakpastian karena adanya faktor prediksi terhadap kecenderungan lingkungan bisnis yang bergerak sangat aktif. Perusahaan harus mampu melihat kecenderungan perkembangan teknologi, yang bisa berpengaruh terhadap kualitas dan kuantitas sumber daya manusia perusahaan di masa yang akan datang. Merancang sumber daya manusia secara efektif supaya seimbang dengan kebutuhan perusahaan demi terwujudnya tujuan perusahaan. Perorganisasian sumber daya manusia dilakukan semata-semata dengan tujuan organisasi guna memaksimalkan performa, produktivitas meningkat, penetapan kebutuhan sumber daya manusia sesuai dengan pembagian tugas dan memakmurkan organisasi. Pengaruh antar variabel ini (manusia atau SDM dan perorganisasian) sudah banyak diteliti oleh peneliti sebelumnya diantaranya: (MYS, Barusman dan MR Saputra,2013), (A Prayudi, 2018),( A Arifudin, S Sudirman, M Andri 2017).

\section{Pengaruh tujuan organisasi terhadap Pengorganisasian}

Menurut salah satu para ahli tujuan organisasi merupakan proses pengklasifikasian pekerjaan individu atau kelompok yang harus dilakukan dengan keahlian yang diperlukan untuk melaksanakan tugas-tugas dengan sedemikan rupa, memberikan saluran terbaik untuk penggunaan yang efisien, sistematis, positif, dan terkoordinasi dari usaha yang sudah tersedia. (Oliver Sheldon 1923). Berdasarkan asas tujuan organisasi, target pencapaian organisasi harus jelas dan rasional, apakah bertujuan untuk mendapatkan laba (organisasi bisnis) ataukah untuk memberikan pelayanan (organisasi public). Berikut merupakan salah 
satu bagian penting dalam menetapkan struktur organisasi. Dalam suatu organisasi (perusahaan) kesatuan ketujuan yag dicapai. Organisasi secara menyeluruh dari tiap-tiap bagiannya harus berusaha guna mencapai tujuan. Organisasi akan kacau bila tidak adanya kesatuan tujuan. Pengaruh antar variabel ini (tujuan organisasi dan perorganisasian) sudah banyak diteliti oleh peneliti sebelumnya diantaranya: (NURASIAH, 2016),(ZEGA, 2021),

(SAPUTRA, 2020).

\section{Pengaruh struktur organisasi terhadap Pengorganisasian}

Menurut Para ahli Struktur organisasi adalah untuk menunjukkan bagaimana tugas pekerjaan secara formal dibagi, dikelompokkan dan dikoordinasikan secara formal. (how job tasks are formally dividend, grouped, and coordinated). Robbins \& Judge (2014 :231) Struktur organisasi atau desain organisasi dapat didefenisikan sebagai mekanisamemekanisme formal dengan mana organisasi dikelola, adapun faktor-faktor utama yang menentukan perancangan dari struktur organisasi adalah:

a) Strategi organisasi dalam mencapai tujuan.

b) Teknologi yang dipergunakan.

c) Anggota (karyawan) dan orang-orang yang terlibat didalamnya.

Ukuran organisasi, makin besar organisai maka struktur organisasi akan semakin kompleks sehingga harus dipilih bentuk struktur organisasi yang tepat. Struktur organisasi terdiri dari:

a) Spesialis kegiatan.

b) Standarisasi kegiatan.

c) Koordinasi kegiatan.

d) Sentralisasi dan desentralisasi pembuatan keputusan.

e) Ukuran suatu kerja menunjukkan jumlah karyawan.

Pengorganisasian merupakan proses rangkaian struktur organisasi yang sejalan dengan tujuan dasar organisasi, sumber daya yang dimiliki serta lingkungan yang melingkupinya. Aspek utama pada proses rangkaian struktur organisasi adalah departementalisai dan pembagian kerja. Berikut ini langkah-langkah prosedur perorganisasian:

a) Pembagian seluruh pekerjaan yang harus dikerjakan guna mencapai tujuan organisasi.

b) Pembagian beban pekerjaan menjadi aktivitas secara logis dapat dikerjakan oleh individual.

c) Pengembangan suatu metode untuk mengkoordinasikan pekerjaan para anggota organisasi menjadi kesatuan yang terpadu dan harmonis.

Pengaruh antar variabel ini (struktur organisasi dan perorganisasian) sudah banyak diteliti oleh peneliti sebelumnya diantaranya: (N SAVTTRI ,A Kesumarati dan MK Zen , 2008), (Anto, 2015), (Prasetiyo.) 


\section{Conceptual Framework}

Berdasarkan rumusan masalah penulisan artikel dan kajian studi literature review yang beersumber dari buku dan artikel yang relevan, maka di perolah rangka artikel ini seperti yang tertera dibawah ini.

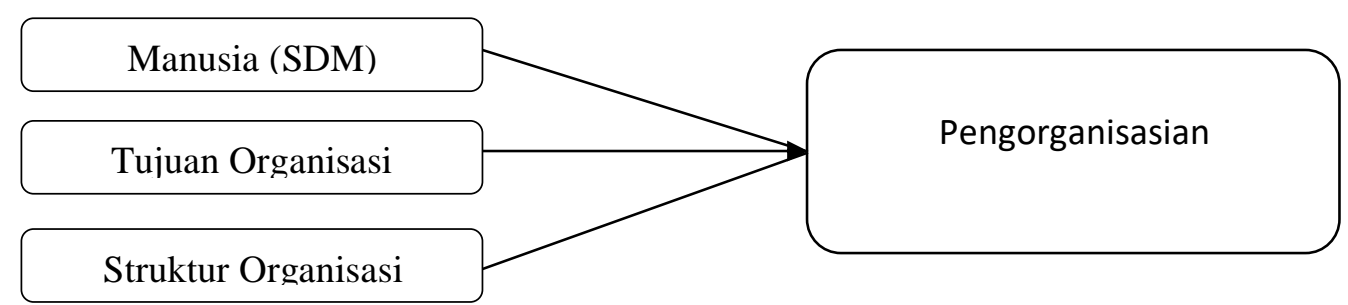

Figure 1: Conceptual Framework

Berdasarkan Kajian teori dan review hasil dari artikel yang relevan serta gambar dari conceptual framework, maka: Sumber Daya Manusia, Tujuan, dan Struktur Organisasi.berpengaruh terhadap Pengorganisasian. Selain dari tiga variabel exogen ini yang mempengaruhi Pengorganisasian, masih banyak variabel lain yang mempengaruhinya diantaranya adalah:

a) Kepemimpinan: (Limakrisna et al., 2016), (Bastari et al., 2020), (Anwar et al., 2020), (Ali et al., 2016), (Djoko Setyo Widodo, P. Eddy Sanusi Silitonga, 2017), (Chauhan et al., 2019), (Elmi et al., 2016).

b) Lingkungan Kerja: (Purba et al., 2017), (Sardjijo \& Ali, 2017)

c) Motivasi: (Riyanto et al., 2017), (Prayetno \& Ali, 2017), (Chauhan et al., 2019), (Rivai et al., 2017), (Prayetno \& Ali, 2017), (Bastari et al., 2020), (Masydzulhak et al., 2016), (Aima et al., 2017)

\section{KESIMPULAN DAN SARAN \\ Kesimpulan}

Berdasarkan rumusan artikel dari pembahasan tersebut maka dapat di di rumuskan hipotesis untuk riset selanjutnya:

1. Sumber Daya Manusia berpengaruh terhadap perorganisasian. Manusia atau sumber daya manusia yang berkualitas dan memiliki kompetensi akan mempengaruhi terhadap perorganisasian

2. Tujuan organisasi berpengaruh terhadap pengorganisasian. Tujuan organisasi yang tepat guna dan dapat meningkatkan kualitas organisasi akan mempengaruhi terhadap perorganisasian. 
3. Struktur organisasi berpengaruh terhadap pengorganisasian. Struktur organisasi yang terarah akan mempengaruhi terhapar perorganisasian

\section{Saran}

Berdasarkan kesimpulan tersebut, maka saran yang terkandung dalam artikel ini adalah bahwa masih banyak faktor lain yang dapat mempengaruhi Pengorganisasian, selain dari Sumber Daya Manusia, Tujuan, dan Struktur Organisasi. pada semua jenis dan level organisasi atau perusahaan, oleh karena itu sangat di perlukan kajian yang selanjutnya untuk mencari faktor-faktor apa saja yang dapat memepengaruhi Pengorganisasian selain varibel yang telah di teliti pada arikel ini. Faktor lain tersebut seperti Tugas dan Lingkungan/Sosial Budaya.

\section{DAFTAR RUJUKAN}

Aima, P. H., Adam, R., \& Ali, P. H. (2017). Model of Employee Performance : Competence Analysis and Motivation (Case Study at PT. Bank Bukopin, Tbk Center). Journal of Research in Business and Management.

Ali, H., Mukhtar, \& Sofwan. (2016). Work ethos and effectiveness of management transformative leadership boarding school in the Jambi Province. International Journal of Applied Business and Economic Research.

Anwar, K., Muspawi, M., Sakdiyah, S. I., \& Ali, H. (2020). The effect of principal's leadership style on teachers' discipline. Talent Development and Excellence.

Ali, H., \& Limakrisna. (2013). Metode Penelitian Petunjuk Praktis untuk Memecahkan Masalah Bisnis. Jakarta: Universitas Terbuka.

Barusman, M. Y., \& Saputra, M. R. (2013). Analisis Pengawasan dan Perencanaan Sumber Daya Manusia Terhadap Kinerja Pegawai PT. Bank Lampung Kantor Cabang Pembantu Sukadana Provinsi Lampung. Jurnal Manajemen dan Bisnis, 4(1), 1-125.

Bastari, A., -, H., \& Ali, H. (2020). DETERMINANT SERVICE PERFORMANCE THROUGH MOTIVATION ANALYSIS AND TRANSFORMATIONAL LEADERSHIP. International Journal of Psychosocial Rehabilitation. https://doi.org/10.37200/ijpr/v24i4/pr201108

Chauhan, R., Ali, H., \& Munawar, N. A. (2019). BUILDING PERFORMANCE SERVICE THROUGH TRANSFORMATIONAL LEADERSHIP ANALYSIS, WORK STRESS AND WORK MOTIVATION (EMPIRICAL CASE STUDY IN STATIONERY DISTRIBUTOR COMPANIES). Dinasti International Journal of Education Management And Social Science. https://doi.org/10.31933/dijemss.v1i1.42

Corkindale, G. (2011, February 11). The Importance of Organizational Design and Structure. Retrieved from Harvard Business Review: https://hbr.org/2011/02/the-importanceof-organization

Djamarah, S. B., \& Zain, A. (2017). Strategi Belajar Mengajar. Jakarta: Rineka Cipta.

Djoko Setyo Widodo, P. Eddy Sanusi Silitonga, \& H. A. (2017). Organizational Performance: Analysis of Transformational Leadership Style and Organizational Learning. Saudi Journal of Humanities and Social Sciences. 
https://doi.org/10.21276/sjhss.2017.2.3.9

Elmi, F., Setyadi, A., Regiana, L., \& Ali, H. (2016). Effect of leadership style, organizational culture and emotional intelligence to learning organization: On the Human Resources Development Agency of Law and Human Rights, Ministry of Law and Human Rights. International Journal of Economic Research.

Harini, S., Hamidah, Luddin, M. R., \& Ali, H. (2020). Analysis supply chain management factors of lecturer's turnover phenomenon. International Journal of Supply Chain Management.

Hasibuan, M. S. (2011). Manajemen Sumber Daya Manusia. Jakarta: PT.Bumi Askara.

Hasibuan, M. S. (2016). Manajemen Sumber Daya Manusia Edisi Revisi. Jakarta: PT. Bumi Aksara.

Irham, F. (2016). Manajemen Sumber Daya Manusia. Bandung: ALFABETA.

Limakrisna, N., Noor, Z. Z., \& Ali, H. (2016). Model of employee performance: The empirical study at civil servants in government of west java province. International Journal of Economic Research.

Masydzulhak, P. D., Ali, P. D. H., \& Anggraeni, L. D. (2016). The Influence of work Motivationand Job Satisfaction on Employee Performance and Organizational Commitment Satisfaction as an Intervening Variable in PT. Asian Isuzu Casting Center. In Journal of Research in Business and Management.

Mayston. (2003). Hambatan Pengorganisasian. Jakarta.

Moekijat. (2016). Perencanaan Sumber Daya Manusia. Bandung: Mandar Maju.

Mondy, R. a. (1995). Management : Concepts, Practices and Skills. New Jersey: Pretince Hall Inc Englewood Cliffs.

Mondy, R. W. (2005). Human Resource Management Ninth Edition. USA: Prentice Hall.

Mooney, J. D. (1996). Konsep Pengenbangan Organisasi Publik. Bandung: Sinar Baru Algesindo.

Prayetno, S., \& Ali, H. (2017). Analysis of advocates organizational commitment and advocates work motivation to advocates performance and its impact on performance advocates office. International Journal of Economic Research.

Purba, C. B., Arzio, \& Ali, H. (2017). The influence of compensation, working environment and organization culture on working productivity of BPJS (workers social security agency) employment staff in Rawamangun Branch. Man in India.

Ridwan, M., Mulyani, S. R., \& Ali, H. (2020). Building behavior and performance citizenship: Perceived organizational support and competence (case study at SPMI private university in west Sumatra). International Journal of Psychosocial Rehabilitation. https://doi.org/10.37200/IJPR/V24I6/PR260195

Rivai, A., Suharto, \& Ali, H. (2017). Organizational performance analysis: Loyalty predictors are mediated by work motivation at urban village in Bekasi City. International Journal of Economic Research.

Riyanto, S., Sutrisno, A., \& Ali, H. (2017). International Review of Management and Marketing The Impact of Working Motivation and Working Environment on Employees Performance in Indonesia Stock Exchange. International Review of Management and Marketing. 
Sardjijo, S., \& Ali, H. (2017). Integrating Character Building into Mathematics and Science Courses in Elementary School. International Journal of Environmental and Science Education. https://doi.org/10.1007/s10648-016-9383-1

Winardi. (2008). Motivasi dan Pemotivasian Dalam Manajemen . Jakarta: Raja Grafindo Jakarta. 